\title{
Slowly progressive Parkinson syndrome due to thalamic butterfly astrocytoma
}

田

Figure MRI, MR-spectroscopy, and histopathology
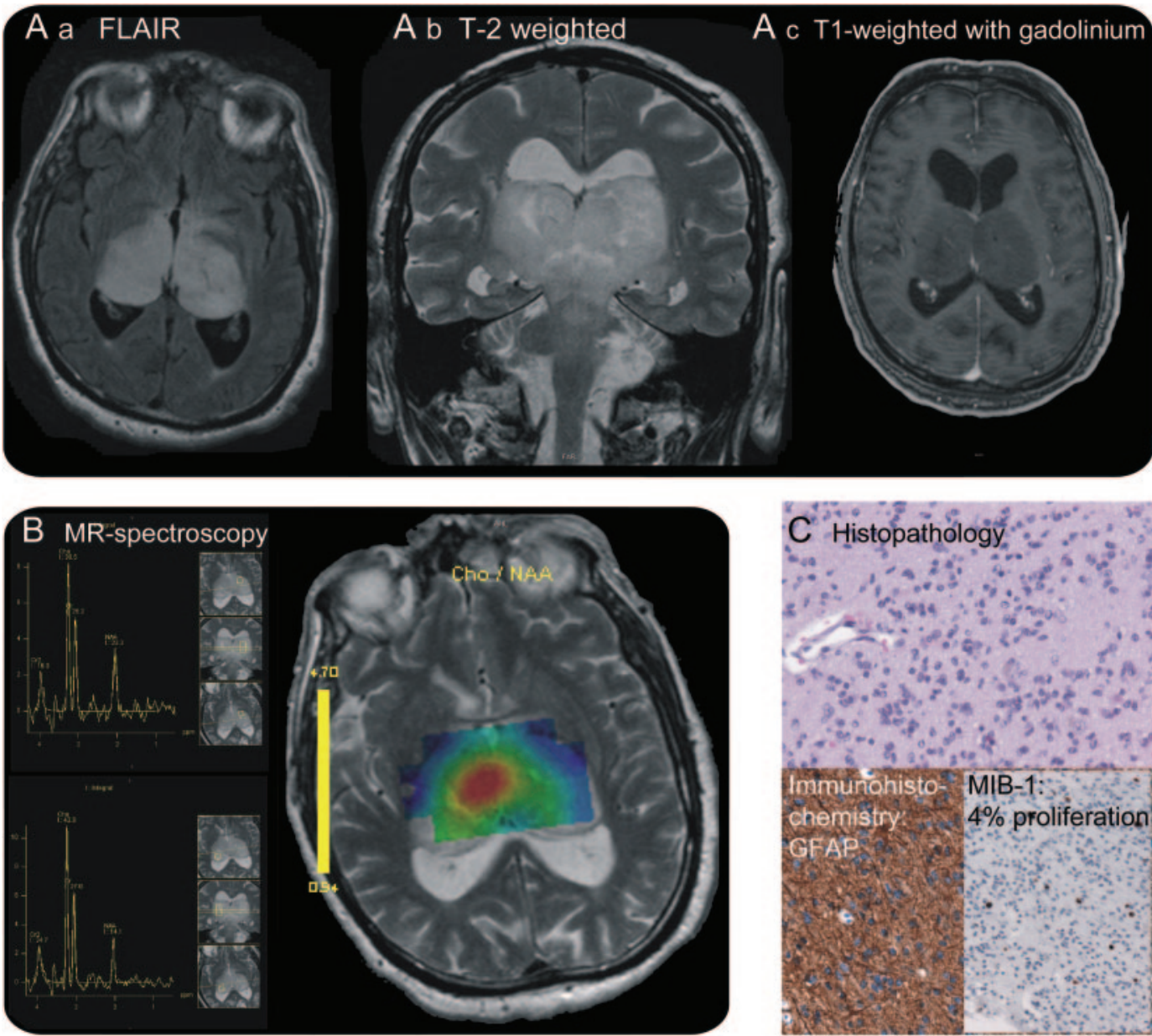

MRI shows a thalamic butterfly-shaped tumor, including the cerebral peduncles and pons (A.a-A.b) without enhancement in T1-weighted images (A.c). Magnetic resonance (MR) spectroscopy shows markedly increased choline with decreased $\mathrm{N}$-acetylaspartate peak and metabolic hot spot (B), suggestive of a high-grade glioma, verified by histopathology displaying glial fibrillary acid protein (GFAP)-positive tumor cells with mitoses and proliferative activity (C). FLAIR = fluid-attenuated inversion recovery.

Supplemental data at www.neurology.org

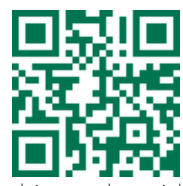

Scan this code with your smartphone to access this feature
A 74-year-old man had a 4-year history of slowly progressive asymmetric resting tremor, hypokinesia, rigidity, and postural instability and mild cognitive decline, initially diagnosed as Parkinson disease. Clinical response to levodopa was moderate (video on the Neurology ${ }^{\circledR}$ Web site at www.neurology.org). Additional pyramidal signs developed; cranial MRI showed a symmetric bilateral tumor of the thalamus and brainstem (figure, A and B). Biopsy revealed an anaplastic astrocytoma grade III (figure, C). Even though parkinsonism caused by a tumor is rare, ${ }^{1}$ brain imaging should be considered early when presenting with atypical clinical signs or poor levodopa response, so as to exclude potentially treatable structural causes.

T. Wächter, $M D,{ }^{*} M$. Engeholm, $M D$, ${ }^{*}$. Bisdas, $M D$, J. Schittenhelm, $M D, T$. Gasser, $M D, R$. Krüger, $M D$, Tübingen, Germany 
*These authors contributed equally.

Author contributions: Tobias Wächter: drafting and revision of the manuscript, analysis and interpretation of data, acquisition of data, study coordination. Maik Engeholm: revision of the manuscript, study concept, analysis and interpretation of data, acquisition of data. Sotirios Bisdas: revision of the manuscript, analysis and interpretation of data, acquisition of data. Jens Schittenhelm: revision of the manuscript, analysis and interpretation of data, acquisition of data, Thomas Gasser: revision of the manuscript, study supervision. Rejko Krüger: revision of the manuscript, study concept and design, analysis and interpretation of data, acquisition of data, study supervision, and coordination.

Disclosure: Dr. Wächter has received funding for travel and speaker honoraria from Medtronic, Inc., Solvay Pharmaceuticals, Inc., Abbott, Cephalon, Inc., and Schwarz Pharma; and holds stock in Gilead Sciences, Inc. Dr. Engeholm reports no disclosures. Dr. Bisdas serves on the editorial advisory board for Radiology Research and Practice. Dr. Schittenhelm has received research support from Merck Serono. Dr. Gasser serves on the editorial boards of Movement Disorders, Parkinsonism and Related Disorders, and the Journal of Neurology; holds a patent re: The LRRK2 gene and neurodegenerative disorders; serves as a consultant for Cephalon, Inc. and Merck Serono; serves on the speakers' bureaus of Novartis, Merck Serono, Schwarz Pharma, Boehringer Ingelheim, and Valeant Pharmaceuticals International; and receives research support from Novartis, the Federal Ministry of Education and Research (BMBF), the Helmholtz Association, and the European Union. Dr. Krüger has received speaker honoraria and/or funding for travel from UCB, Cephalon, Inc., Abbott, Takeda Pharmaceutical Company Limited, and Medtronic, Inc.; serves on the editorial advisory boards of the European Journal of Clinical Investigations, the Journal of Neural Transmission, and BMC Neurology; and receives research support from the German Research Council (DFG), the Michael J Fox Foundation, the Federal Ministry for Education and Research (BMBF), and the Medical Faculty of the University of Tübingen.

Address correspondence and reprint requests to Dr. Rejko Krüger, Department for Neurodegenerative Diseases and Hertie Institute for Clinical Brain Research and German Center for Neurodegenerative Diseases, University of Tübingen, Hoppe-Seyler-Str. 3, D-72076

Tübingen, Germany; rejko.krueger@uni-tuebingen.de

1. Ho BL, Lieu AS, Hsu CY. Hemiparkinsonism secondary to an infiltrative astrocytoma. Neurologist 2008;14:258-261.

\section{NeuroImages Are Free at www.neurology.org!}

All Neurology ${ }^{\circledR}$ NeuroImages can now be freely accessed on the Neurology Web site. See them at www.neurology.org, where you can also sign up for journal email alerts and check out other online features, including the Resident \& Fellow section, Neurology: Clinical Practice, and the weekly Neurology Podcasts. 


\section{Neurology}

Slowly progressive Parkinson syndrome due to thalamic butterfly astrocytoma

T. Wächter, M. Engeholm, S. Bisdas, et al.

Neurology 2011;77;404-405

DOI 10.1212/WNL.0b013e3182267bc4

This information is current as of July 25, 2011

Updated Information \&
Services

Supplementary Material

References

Subspecialty Collections

Permissions \& Licensing

Reprints including high resolution figures, can be found at:

http://n.neurology.org/content/77/4/404.full

Supplementary material can be found at:

http://n.neurology.org/content/suppl/2011/07/22/77.4.404.DC1

This article cites 1 articles, 0 of which you can access for free at: http://n.neurology.org/content/77/4/404.full\#ref-list-1

This article, along with others on similar topics, appears in the following collection(s):

MRI

http://n.neurology.org/cgi/collection/mri

Parkinson's disease/Parkinsonism

http://n.neurology.org/cgi/collection/parkinsons_disease_parkinsonism Primary brain tumor

http://n.neurology.org/cgi/collection/primary_brain_tumor

Information about reproducing this article in parts (figures,tables) or in its entirety can be found online at:

http://www.neurology.org/about/about_the_journal\#permissions

Information about ordering reprints can be found online:

http://n.neurology.org/subscribers/advertise

Neurology ${ }^{\circledR}$ is the official journal of the American Academy of Neurology. Published continuously since 1951, it is now a weekly with 48 issues per year. Copyright Copyright $@ 2011$ by AAN Enterprises, Inc.. All rights reserved. Print ISSN: 0028-3878. Online ISSN: 1526-632X.

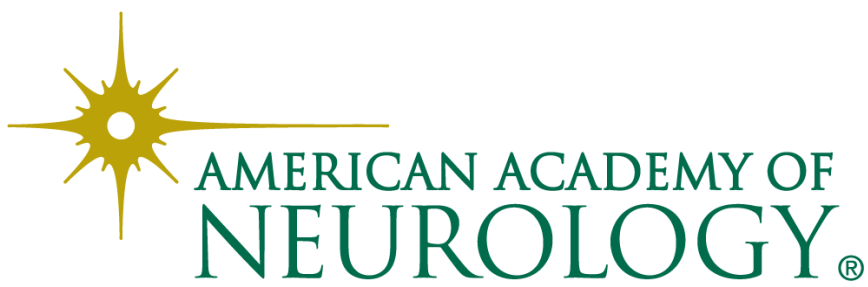

